\title{
THE PERFORMANCE OF ADVANCED III-V SOLAR CELLS ${ }^{+}$
}

\author{
Robert L. Mueller \\ Jet Propulsion Laboratory, California Institute of Technology, Pasadena, CA 01109 \\ Edward Gaddy \\ NASA Goddard Space Flight Center, Greenbelt, MD 20771
}

\begin{abstract}
Test results show triple junction solar cells with efficiencies as high as $27 \%$ at $28 \mathrm{C}$ and $136.7 \mathrm{mw} / \mathrm{cm}^{2}$. Triple junction cells also achieve up to $27.5 \%$ at $-120 \mathrm{C}$ and $5 \mathrm{mw} / \mathrm{cm}^{2}$, conditions applicable to missions to Jupiter. Some triple junction cells show practically no degradation as a result of Low Intensity Low Temperature (LILT) effects, while others show some; this degradation can be overcome with minor changes to the cell design.
\end{abstract}

\section{INTRODUCTION}

In the last decade solar cell efficiencies have increased by over $50 \%$ with significant improvements in the last year. This paper provides data for recently manufactured triple junction Gallium Arsenide (GaAs) based solar cells from three manufacturers: Emcore, Spectrolab, and Tecstar.

This data is from solar cell samples taken from production lots from each of the manufacturers. However, some differences may be expected between these cells and average production cells as the authors did not require the selection of cells representing the average of a production lot.

\section{TEST CONDITIONS}

Table I provides the intensity versus temperature matrix which defines the conditions under which the cells were tested. This matrix was devised to include three temperatures, $0 \mathrm{C}, 10 \mathrm{C}$ and $28 \mathrm{C}$, common to all intensities. This was done to observe the effects of intensily change on cell output.

Table I

Cell Test Conditions

\begin{tabular}{|c|c|}
\hline $\begin{array}{c}\text { Intensity } \\
\left(\mathrm{mw} / \mathrm{cm}^{2}\right)\end{array}$ & $\begin{array}{c}\text { Test Temperatures } \\
(\mathrm{C})\end{array}$ \\
\hline 5 & $-120,-100,-80,-70,-50,-30$, \\
& $-10,0,10,28$ \\
\hline 58.4 & $-50,-30,-10,0,10,28$ \\
\hline 136.7 & $0,10,28,50,70$ \\
\hline
\end{tabular}

\section{CELLS TESTED}

Tests were run on Emcore, Spectrolab, and Tecstar, bare, triple-junction solar cells. Protection diodes were present on the Tecstar cells, but were not connected. Protection diodes were not used at all on the Emcore and Spectrolab cells. Table II summarizes the cell characteristics.

Table II

Cell Characteristics

\begin{tabular}{|c|c|c|}
\hline Manufacturer & Area in $\mathrm{cm}^{2}$ & Thickness in Microns \\
\hline Emcore & 27.48 & 140 \\
\hline Spectrolab & 26.70 & 190 \\
\hline Tecstar & 30.20 & 178 \\
\hline
\end{tabular}

\section{TEST DESCRIPTION}

Prior to the characterization tests, the cells were electrically checked for low shunt resistance and visually examined for cracks to determine their condition. All were in good shape. Following the bonding of cells to copper test plates, they were similarly rechecked and were also checked for electrical isolation from the lest plate. The cells still appeared to be in good condition and were well isolated from their test plates.

An additional inspection of the bonded Emcore cells under $X-25$ illumination showed that two of the cells appeared to have $0.5 \mathrm{~cm}$ long and wide " $X$ " cracks that were barely perceptible and initially thought to be scratches. Electrical checks using the X-25 solar simulator and a Large Area Pulsed Solar Simulator (LAPSS) sel to $136.7 \mathrm{~mW} / \mathrm{cm}^{2}$ intensity and a cell temperature of $28 \mathrm{C}$ showed no particular difference in the performance of these cells and the other cells on the test plates.

Unfortunately, the LAPSS subjected the first Emcore cell tested to reverse bias that severely degraded it. This would not have happened had the cell had its protection diode connected.

During the testing that followed, which thermally stressed the cells somewhat, the cracks in the two

\footnotetext{
${ }^{\dagger}$ This work was sponsored by the National Aeronautics and Space Administration through Goddard Space Flight Center
} 
Emcore cells mentioned above each propagated across the entire cell. This noticeably influenced cell performance. Cracks also occurred on an Emcore cell, a Spectrolab cell and a Tecstar cell. This established the number of good Emcore cells to four, Spectrolab cells to seven, and Tecstar cells to seven. The stresses the cells endured during these tests is expected to be higher than in space flight due to their mounting on a copper plate as opposed to a graphite face sheet substrate or similar. The adhesive used to fix the cells to the plate was NuSil CV-2568 Silicone Elastomer, which is similar to G.E. RTV-566 with small glass beads. NuSil $\mathrm{SP}-120$ Clear Primer was also used sparingly. Some of the cracks were possibly in the cells at delivery, some were probably caused during the interconnect soldering, cell to plate bonding, or cell cleaning. It is difficult to conclude exactly when an individual cell was damaged However, two things are clear. Care must be taken when handling these relatively thin cells and the thinner cells are more prone to damage.

Initial tests were used to compare results from the $X-25$ and the LAPSS. It was obvious that the LAPSS, which did not have the latest filtering available from Spectrolab, lacked sufficient infrared to adequately power the bottom, Germanium, junction. Therefore, all of the characterization tests used a modified Spectrolab $x-25$ solar simulator. The simulator modification refers to a set of adjustable filters used to correct the spectrum to simultaneously produce the proper calibration value from both the top and middle junction balloon standards of dual junction solar cells. A separate set of ballooncalibrated standards from each manufacturer was used to setup the $X-25$. In addition, I-V curves of the test cells were all obtained with an active load (bi-polar power supply) that had a diode circuit across its output to limit the reverse voltage across any test cell to 0.7 volts. The results of these tests are shown in Figure 1 below. The manufacturers are not identified by name because the authors are not certain about how each manufacturer selected cells from the production lots.

\section{LILT EFFECTS}

It is clear that the manufacturers represented by the squares and the diamonds suffer from LILT effects. Both of the manufacturers have stated that they can relatively easily eliminate these effects.

The LILT effects can be caused by at least two different defects, a diode in the contact metalization and a low internal shunt resistance. These tests show both defects.

Figure 2 shows a LILT effect in an I-V curve that results in a "flat" near the peak power point due to an diode in the metallization. Figure 3 below shows the LILT effect due to low internal shunt resistance which results in decreasing current as a function of increasing voltage in the curve's "constant current" region.

Figure 1

Efficiency of Triple Junction Cells from Three Manufacturers as a

Function of Temperature at Intensities of $5,58.4$, and $136.7 \mathrm{mw} / \mathrm{cm}^{2}$

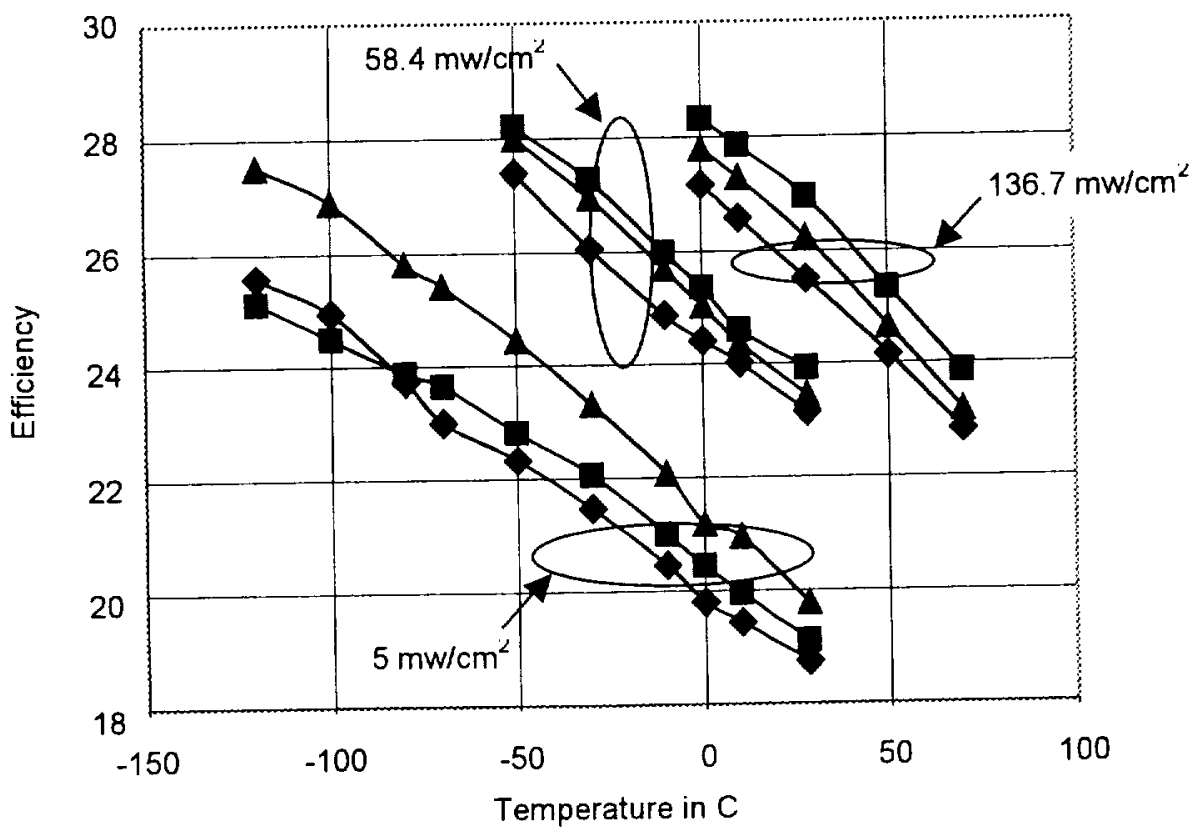



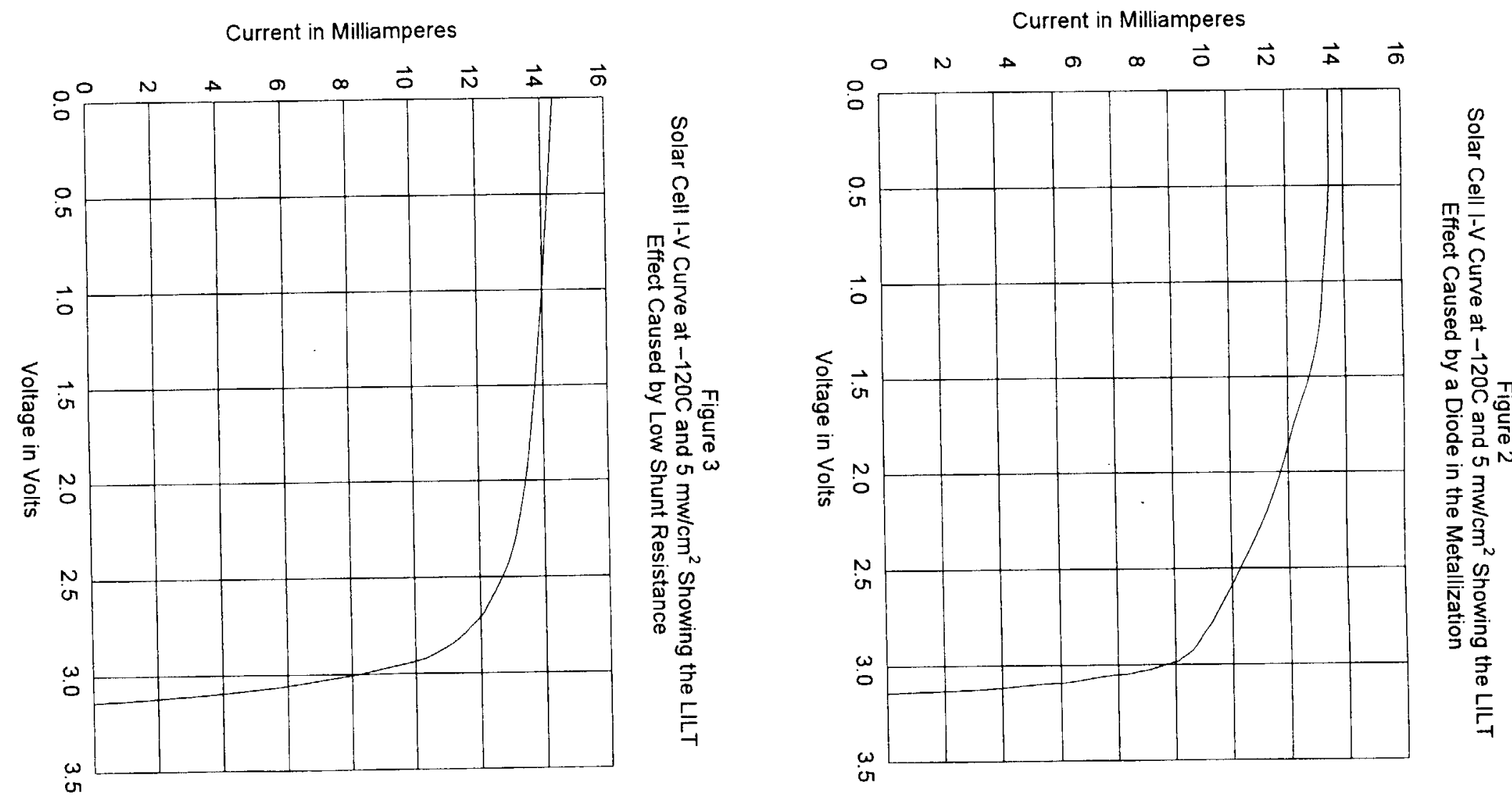
Figure 4

Solar Cell I-V Curve at $-120 \mathrm{C}$ and $5 \mathrm{mw} / \mathrm{cm}^{2}$ Showing

Negligible LILT Effects

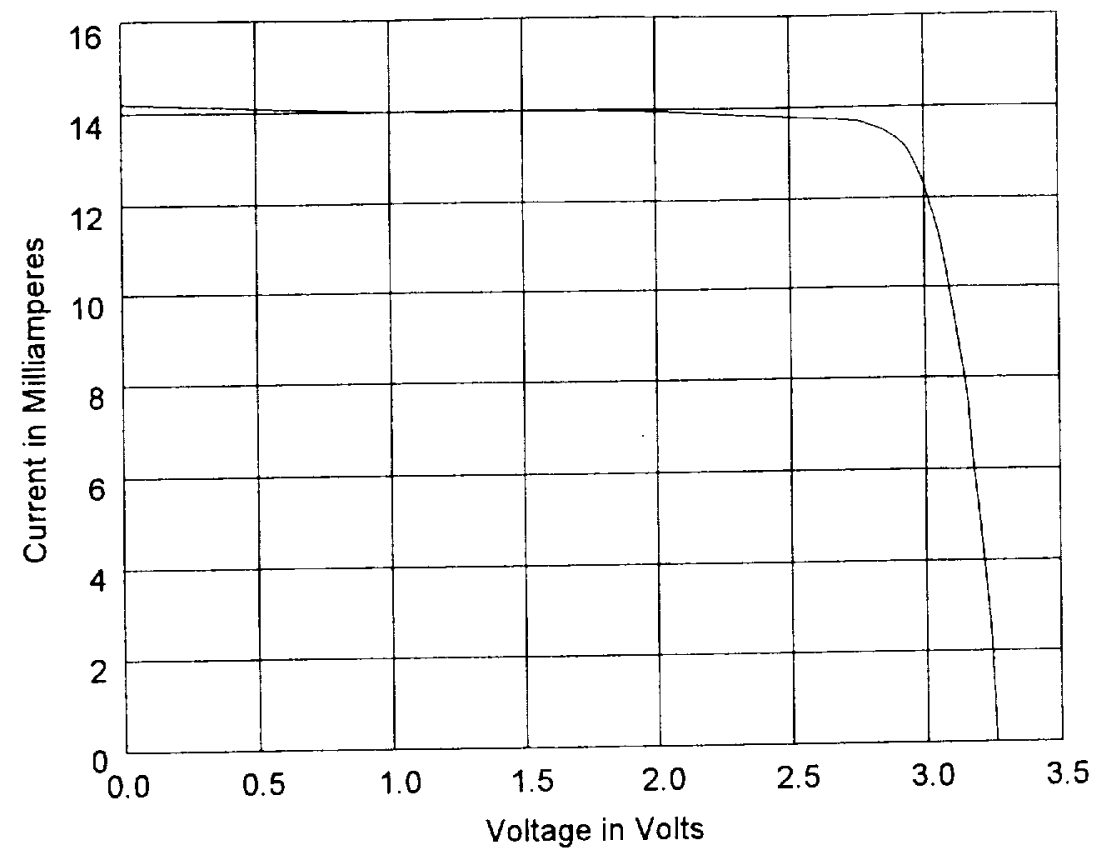

Figure 4 shows an $1-V$ curve at $-120 \mathrm{C}$ and $5 \mathrm{mw} / \mathrm{cm} 2$ that shows negligible LILT effects.

\section{CONCLUSION}

All the cells tested demonstrated efficiencies that were unobtainable even a short time ago. ${ }^{1}$ While some triple junction solar cells exhibited LILT effects that were detrimental to cell efficiency, one manufacturer has shown that it is possible to fabricate cells that do not show LILT effects. All of the manufacturers have stated the causes of the effects are known and that they can be easily eliminated.

${ }^{1}$ Paul Stella, Gregory Davis, Robert Mueller, Dmitri Krut, David Brinker, David Scheiman, The Performance of Advanced Solar Cells for Interplanetary Missions, Twentieth IEEE PVSC, 2000, pp. 1354 - 1357. 


\section{IEEE COPYRIGHT TRANSFER \& EXPORT CONTROL COMPLIANCE FORM}

To insure uniformity of treatment among all contributors, other forms may not be substituted for this form, nor may any wording of the form be changed. This form is intended for original material submitted to IEEE and must accompany any such material in order to be published by IEEE. Please read the form carefully and keep a copy for your files.

TITLE OF PAPER/ARTICLE'REPORT/PRESENTATION/SPEECH (hereinafter, "the Work"):

\section{COMPLETE LIST OF AUTHORS:}

IEEE PUBLICATION (Journal, Magazine, Conference, Book) TITLE:

\section{Copyright Transfer}

The undersigned hereby assigns all rights under copyright and the Copyright Act, 17 U.S.C. $\$ 101$ et seq. that may exist in and to the above Work to The Institute of Electrical and Electronics Engineers Inc. (the "IEEE"). The undersigned hereby warrants that the Work is original and that he/she is the author of the Work; to the extent the Work incorporates text passages, figures, data or other material from the works of others, the undersigned has obtained any necessary permissions. The undersigned further warrants that the publication or dissemination of the Work shall not violate any proprietary right or the Digital Copyright Millennium Act (the "DCMA").

\section{Export Control Law Compliance}

The IEEE, a not-for-profit organization headquartered in the State of New York in the United States of America, distributes its technical publications throughout the world and wants to ensure that the material submitted to its publications is properly available for general dissemination to the readerstip of those publications. The undersigned hereby certifies that (1) the information contained in any materials submitted to the IEEE nn connection with the Work is not subject to any restriction related to its disclosure, because it is not defense-related, classified, or subject to any other disclosure restrictions by any govemment, including the United States government, that has authority to restrict the dissemination of such information, (2) any and all necessary authorization(s) from the undersigned's employer(s) for the disclosure of the infomation discussed in the Work have been obtained; and (3) the foregoing applies to all future versions of the Work, edited by the undersigned, an assistant co-author os any person working with the undersigned. If the information is subject to any disclosure restrictions, the undersigned certifies that all necessary writter authorization(s) for its public disclosure have been obtained and are attached herewith. IEEE reserves the riglit to refuse publication of the Work or participation at a conference for failure to certify the foregoing.

\section{General Terms}

The undersigned represents that he/she has the power and authority to make and execute this assignment.

The undersigned agrees to indemnify and hold harmless IEEE from any damage or expense that may arise in the event of a breach of any of the warranties set forth above.

In the event the above work is not accepted and published by the IEEE or is withdrawn by the author(s) before acceptance by the IEEE, this form agreement becomes null and void and all materials submitted to the IEEE will be destroyed in accordance with IEEE's export compliarce program.

(1).

Anthor/Authorized Agent for Joint Authors

Date

(For jointly authored Works, all joint authors should sign, or one of the authors should sign as authorized agent for the others.)

\section{U.S. Government Emplovee Certification (where applicable)}

This will certify that all authors of the Work are U.S. govemunent employees and prepared the Work on a subject within the scope of their official duties. As such, the Work is not subject to U.S. copyright protection.

(2)

Authorized Signature
Date

(Authors who are U.S. govermment employees should also sign signature line (1) above to enable IEEE to clainn and protect its copyright in international jurisdictions) 


\section{RETAINED RIGHTS/TERMS AND CONDITIONS}

1. Authors/employers retain all proprietary rights in any process, procedure, or article of manufacture described in the Work.

2. Authors/employers may reproduce or authorize others to reproduce the Work, material extracted verbatim from the Work, or derivative works for the author's personal use or for company use, provided that the source and the IEEE copyright notice are indicated, the copies are not used in any way that implies IEEE endorsement of a product or service of any employer, and the copies themselves are not offered for sale.

3. Authors/employers may make limited distribution of all or portions of the Work prior to publication if they inform the IEEE in advance of the nature and extent of such limited distribution.

4. In the case of a Work performed under a U.S. Government contract or grant, IEEE recognizes that the U.S. Government has royalty-free permission to reproduce all or portions of the Work, and to authorize others to do so, for official U.S Government purposes only, if the contract/grant so requires.

For all uses not covered by items 2,3, and 4, authors/employers must request permission from the IEEE Intellectual Property Rights office to reproduce or authorize the reproduction of the Work or material extracted verbatim from the Work, including figures and tables.

Although authors are permitted to re-use all or portions of the Work in other works, this does not include granting third-party requests for reprinting, republishing, or other types of re-use. The IEEE Intellectual Property Rights office must handle all such third-party requests.

\section{INFORMATION FOR AUTHORS}

\section{IEEE Copyright Ownership}

It is the formal policy of the IEEE to own the copyrights to all copyrightable material in its technical publications and to the individual contributions contained the same time to facilitate the appropriate re-use of this material by theren, in order to protect the interests of the IEEE, its authors and their employers, and, at the saratious means such as hard copy, microfiche, microfilm, and

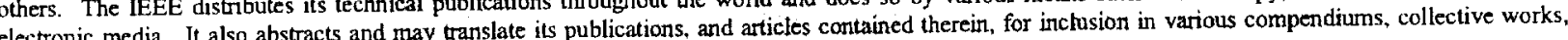
data bases and similar publications.

\section{IEEE Export Control Policy}

It is the formal policy of the IEEE to request the certification set forth above for all the materials submitted for potential publication or disclosure at a it is the for of conferen, in the enclosed form, this indicates that submitted information in accordance with U.S. law. When an article is submitted to the IEEE for publication along with the enclo governmental approvals.

\section{Author/Employer Rights}

If you are employed and prepared the Work on a subject within the scope of your employment, the copyright in the Work belong to your employer as a workfor-hire. In that case, the IEEE assumes that when you sign this Form, you are authorized to do so by your employer and that your employer has consented to

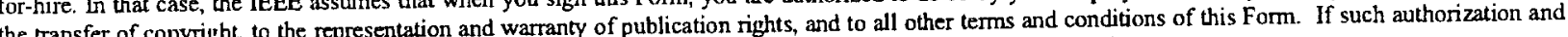
consent has not been given to you, an authorized representative of your employer should sign this Form as the Author.

Further, if you are employed and prepared the materials submitted as a part of such employment, the U.S. export control responsibilities rest initially with your employer. In U.S. export control law. If you decline to do so or act without the consent and/or knowledge of your employer, then the IEEE will refuse to further consider the materials submitted for publication.

\section{Reprint/Republication Policy}

The IEEE requires that the consent of the first-named author and employer be sought as a condition to granting reprint or republication rights to others or for permitting use of a Work for promotion or marketing purposes. 


\section{IEEE COPYRIGHT TRANSFER \& EXPORT CONTROL COMPLIANCE FORM}

To insure uniformity of treatment among all contributors, other forms may not be substituted for this form, nor may any wording of the form be changed. This form is intended for original material submitted to IEEE and must accompany any such material in order to be published by IEEE. Please read the form carefully and keep a copy for your files.

TITLE OF PAPER/ARTICLE/REPORT/PRESENTATION/SPEECH (hereinafter, "the Work"):

\section{COMPLETE LIST OF AUTHORS:}

IEEE PUBLICATION (Journal, Magazine, Conference, Book) TITLE:

\section{Copvright Transfer}

The undersigned hereby assigns all rights under copyright and the Copyright Act, 17 U.S.C. $\S 101$ et seq. that may exist in and to the above Work to The Institute of Electrical and Electronics Engineers Inc. (the "IEEE"). The undersigned hereby warrants that the Work is original and that he/she is the author of the Work; to the extent the Work incorporates text passages, figures, data or other material from the works of others, the undersigned has obtained any necessary permissions. The undersigned further warrants that the publication or dissemination of the Work shall not violate any proprietary right or the Digital Copyright Millennium Act (the "DCMA").

\section{Export Control Law Compliance}

The IEEE, a not-for-profit organization headquartered in the State of New York in the United States of America, distributes its technical publications throughout the world and wants to ensure that the material submitted to its publications is properly available for general dissemination to the readership of those publications. The undersigned hereby certifies that (1) the information contained in any materials submitted to the IEEE in connection with the Work is not subject to any restriction related to its disclosure, because it is not defense-related, classified, or subject to any other disclosure restrictions by any govensment including the United States govemment, that has authority to restrict the dissemination of such information, (2) any and all necessary authorization(s) from the undersigned's employer(s) for the oisclosure of the infornation discussed in the Work have been obtained; and (3) the foregoing applies to all future versions of the Work, edited by the undersigned, antassistant, co-author or any person working with the undersigned. If the information is subject to any djsclosure restrictions, the undersigned certifies that all necessary written authorization (s) for its public disciosure have been obtained and are attached herewith. IEEE reserves the right to refuse publication of the Work or participation at a conference for fajlure to certify the foregoing.

\section{General Terms}

The undersigned represents that he/she has the power and anthority to make and execute this assignment

The undersigned agrees to indernnify and hold harmless IEEE from any damage or expense that may arise in the event of a breach of any of the warranties set forth above.

In the event the above work is not accepted and published by the IEEE or is withdrawn by the author(s) before acceptance by the JEEE, this form agreement becomes mull and void and all materials submitted to the IEEE will be destroyed in accordance with IEEE's export compliance program.
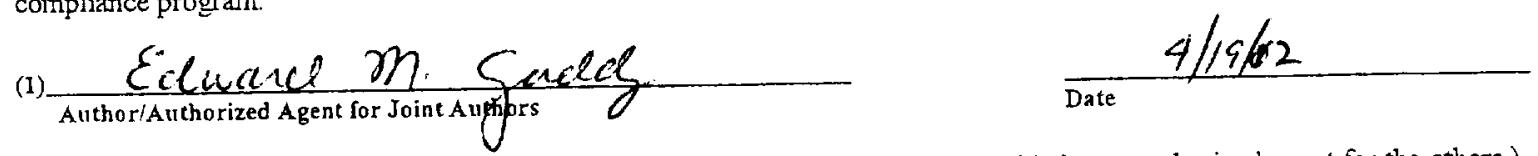

(For jointly authored Works, all joint authors should sign, or one of the authors should sign as authorized agent for the others.)

\section{U.S. Government Employee Certification (where applicable)}

This will certify that all authors of the Work are U.S. govenument employees and prepared the Work on a subject within the scope of their official duties. As such, the Work is not subject to U.S. copyright protection.
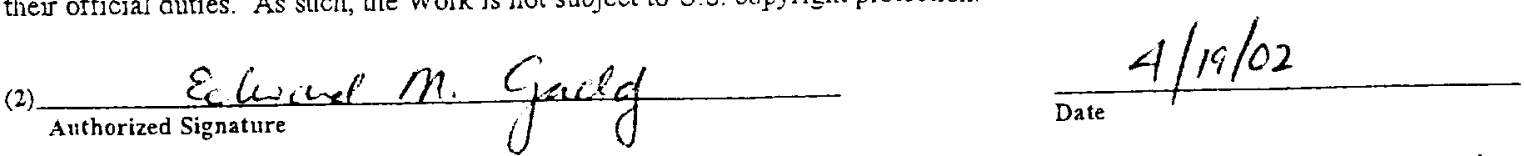

(Authors who are U.S. govemment employees should also sign signature line (1) above to enable IEEE to clainn and protect its copyriglit in international jurisdictions) 


\section{RETAINED RIGHTS/TERMS AND CONDITIONS}

Authors/employers retain all proprietary rights in amy process, procedure, or article of manufacture described in the Work

2.

Authors/employers may reproduce or authorize others to reproduce the Work, material extracted verbatim from the Work, or derivative works for the author's personal use or for company use, provided that the source and the IEEE copyright notice are indicated, the copies are not used in any way that implies IEEE endorsement of a product or service of any employer, and the copies themselves are not offered for sale.

Authors/employers may make limited distribution of all or portions of the Work prior to publication if they inform the IEEE in advance of the nature and extent of such linited distribution.

4.

In the case of a Work performed under a U.S. Government contract or grant, IEEE recognizes that the U.S. Government has royalty-free permission to reproduce all or portions of the Work, and to authorize others to do so, for official U.S. Government purposes only, if the contract/grant so requires.

For all uses not covered by items 2,3, and 4, authors/employers must request permission from the IEEE Intellectual Property Rights office to reproduce or authorize the reproduction of the Work or material extracted verbatim from the Work, jncluding figures and tables.

Although authors are permitted to re-use all or portions of the Work in other works, this does not include granting third-party requests for reprinting, republishing, or other types of re-use. The IEEE Intellectual Property Rights office must handle all such third-party requests.

\section{IEEE Copyright Ownership}

\section{INFORMATION FOR AUTHORS}

It is the formal policy of the IEBE to o wn the copyrights to all copynghtable material in its technical publications and to the individual contibutions contained It is the formal policy of the IEBE to own the copynghts to all copynghabie Jnateras, and the sanne tine, to facilitate the appropnate re-use of this material by

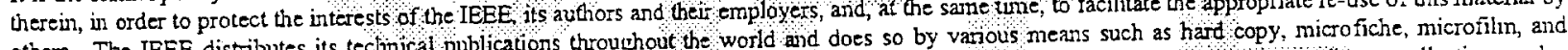
others. The IEEE distributes its teclinjea publications throughout the world and does so by vassous neans such as hare copy andiums, collective works, electronic media. It also abstracts and may translate its publications, and articles conteined therent for ind data bases and similar publications.

\section{IEEE Export Control Palicy}

II is conference, in order to protect the interests of the IEEE, its authors and their employers, and, at the same time, to facilitate the appropriate public release of the submitted information in accordance with. U.S. law. When an article is submitted to the IEEE for publication along with the enclosed form, this indicates that the information is either not subject to any disclosure restrictions or the authors have received all necessary govenumental approvals.

\section{Author/Enplover Rights}

If you are employed and prepared the Work on a subject within the scope of your employment, the copyright in the Work belong to your employer as a workIf the transfer of copyright to the representation and warranty of publication rights, and to ail other terms and conditions of this Form. If such authorization and consent has not been given to you, an authorized representative of your employer should sign this Form as the Author.

Further, if you are employed and prepared the materials submitted as a part of such employment, the U.S. export control responsibilities rest initially with your

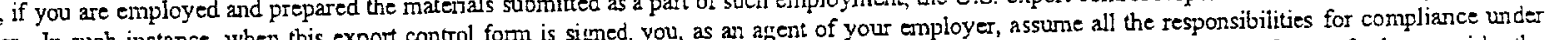
employer. Li such instance, when this export control form is signed, you, as an agent of your employer, assunne all the IEEE will refuse to further consider the U.S. export contol law. If you decline to do so or act without the consent and/or knowiedge of your rnaterials submitted for publication.

\section{Reprint/Republication Policy}

The IEEE requires that the consent of the first-named author and employer be sought as a condition to granting reprint or republication rights to others or for pemitting use of a Work for promotion or marketing purposes. 